\title{
Pengaruh Penggunaan Media Internet Terhadap Minat Belajar Siswa Muslim di SMP Kota Pekanbaru
}

\author{
Devi Arisanti, Mhd. Subhan \\ Universitas Islam Negeri (UIN) Sultan Syarif Kasim Riau \\ Jalan H. R. Soebrantas No. 155 KM. 15 Simpang Baru Panam Pekanbaru \\ Email: deviarisanty@gmail.com/mhd.subhan@uin-suska.ac.id
}

\begin{abstract}
The purpose of this study is to determine the effect of internet media on the learn interest of Muslim student in Pekanbaru. Internet Media is an important role for interest in learn for students. The population of this study is Muslim Students in Pekanbaru. This study used random sampling technique Consisted of 350 Samples. The data collection used two instruments is first, the internet media and second, student learning interest. The instrument reliability test found Cronbach Alpha .86.The instrument of learning interest of students found alpha cronbach .83. Data analysis used SPSS Version 22.0 Software. The results of the study show in descriptive the influence of the internet media as a whole, at high category. But the same with descriptive learn interest students are at high category. In addition, the analysis of inference with regression analysis found the results of research that gave a significant influence on the internet media on learning interest among students, namely $84.6 \%$. Thus it can be concluded that the influence factor of internet media greatly influences the interest in learning for Pekanbaru City Middle School students. Therefore, schools need to create orientation and understanding programs to give students understanding in used internet media with positive things.
\end{abstract}

Keyword: Internet Media, Learning Interest, Muslim Students

Abstrak: Penelitian ini bertujuan untuk mengetahui pengaruh media internet terhadap minat belajar siswa muslim di kota Pekanbaru. Media internet memiliki peranan penting untuk minat belajar bagi kalangan siswa. Populasi penelitian ini merupakan siswa muslim di kota Pekanbaru. Teknik persampelan penelitian ini menggunakan teknik random sampling yang terdiri 350 sampel. Alat pengumpulan data menggunakan dua instrumen yaitu pertama, instrument media internet dan kedua minat belajar siswa. Uji coba reliabilitas instrument mendapati Alpha Cronbach .86.Instrument minat belajar siswa mendapati alpha cronbach .83. Analisis data menggunakan Software SPSS Version 22.0. Hasil Penelitian menunjukkan pada deskriptif pengaruh media internet secara keseluruhan, berada pada tahap tinggi. Namun sama juga dengan deskriptif minat belajar siswa berada pada tahap tinggi. Selain itu, analisis pada inferensi dengan analisis regresi didapati hasil penelitian yang memberi pengaruh signifikan padamedia internet terhadap minat belajar dikalangan siswa yaitu 84.6\%. Dengan demikian dapat disimpulkan faktor pengaruh media internet terhadap minat belajar siswa SMP Kota Pekanbarusangat memberi pengaruh signifikan. Oleh itu, sekolah perlu membuat program orientasi dan pemahaman untuk memberikan kepada siswa kepahaman dalam menggunakan media internet dengan hal yang positif.

Kata Kunci: Media Internet, Minat Belajar, Siswa Muslim 


\section{PENDAHULUAN}

Pendidikan dan pengajaran merupakan masalah yang cukup kompleks dimana banyak faktor yang mempengaruhinya. Salah satu faktor tersebut adalahguru. Guru merupakan komponen pendidikan yang memegang peranan pentingdan utama, karena keberhasilan proses belajar mengajar sangat ditentukan olehguru.

Adapun salah satu tugas guru adalah menyampaikan materi pelajarankepada siswa melalui komunikasi interaktif dalam proses belajar mengajar yangdilakukan. Keberhasilan guru dalam menyampaikan informasi sangat tergantungpada kelancaran interaksi dan komunikasi antara guru dan peserta didik.Ketidaklancaran komunikasi membawa akibat terhadap pesan yang disampaikanoleh guru tidak terterima dengan baik.

Banyak dari guru yang tidak menguasaiteknik mendidik dan mengajar yang menyebabkan siswa malas belajar. Menurut Winkel (1999) menyatakan bahwa pendidikan di sekolah berhasil disebabkan guru yang proaktif, kreatif dan inovasi dalam mendidik dan mengajar siswa di sekolah. Namun demikian fenomena yang terjadi di sekolah pada era globalisasi ini ramainya guru yang kurang berinovasi dan menoton ketika mengajar yang membuat minat belajar siswa rendah untuk belajar. Hasil observasi dari fenomena yang ada di Sekolahditemukanmasalah tentang minat belajar siswa yang masih rendah. Rendahnya minatbelajar siswa yang nampak dari beberapa halseperti pertama, siswa kurang bergairah untuk mengikuti pelajaran, kedua, siswa tidak responsaat guru memberikan pertanyaan di kelas dan ketiga, siswa kurang menyelesaikan tugastugasyang diberikan guru dan tidak mau menanyakan materi pelajaran yangbelum dipahami dan rendahnya minat baca siswa untuk mencari tugas-tugasyang diberikan guru dengan memanfaatkan fasilitas internet yang disediakan oleh pihak sekolah.

Sehubungan dengan masalah rendahnyaminat belajar siswa, maka peneliti mendapati hasil penelitian Marwoto (2014) yang di lakukan kota pekanbaru menyatakan bahwa salah satu upayapemecahan masalah untuk merangsang minat belajar melalui penyediaanfasilitas belajar salah satunya adalah media internet.Internet di bidang pendidikan sangat berguna dalam proses belajarmengajar di sekolah, di mana para siswa dapat melengkapi ilmupengetahuannya, sedangkan guru dapat mencari bahan ajar yang up to datemelalui internet.

Sesuai dengan hasil penelitian Prima Lestati (2012) menjelaskan bahwa penggunaan media internet memberi pengaruh terhadap minat belajar siswa yang menjadikan minat belajar tinggi. Hal ini disebabkan oleh pengaruh adanya inovasi dalam proses pembelajaran dan pengajaran yang dilakukan oleh guru di sekolah.

Menurut Kartono (2003: 21) Minat merupakan moment-moment dari kecendrungan jiwa yang terarah secara intensif kepada suatu obyek yang dianggap paling efektif (perasaan, emosional) yang didalamnya terdapat elemen-elemen efektif (emosi) yang kuat. Minat juga berkaitan dengan kepribadian. Menurut (Syafrudin N. Utomo, 2009) menyatakan pada minat individu terdapat unsur-unsur pengenalan (kognitif), emosi (afektif), dan kemampuan (konatif) untuk mencapai suatu objek, seseorang suatu soal atau suatu situasi yang bersangkutan dengan diri pribadi.

Menurut (Syafrudin, 2009) Individu dapat mencari apa saja melalui internet, mulai dari matapelajaran hingga ilmu pengetahuan umum. Penggunaan internet sebagai mediapendidikan dapat dianggap sebagai suatu hal yang sudah jamak digunakan dikalangan pelajar. Internet sebagai sarana untuk belajar selain dari 
buku jugadapat dijadikan solusi dalam mengatasi rendahnya minat belajar siswa.

Suasana hati (mood) yang baik. Ketika siswa sedang merasakan suasana hati yang tidak menyenangkan karena berbagai perasaan negatif (sedih, tertekan, kecewa, atau marah, sakit), tentu saja ia akan merasakan kesulitan untuk berkonsentrasi dalam belajar. Menurut (Muadz, 2007) menghuraikan bahwa siswa memiliki minat untuk belajar maka didukung oleh fasilitas yang berinovasi seperti internet, sudah bisa dipastikan bahwa siswa tersebut memiliki minat belajar yang tinggi. Pada saat ini sumber-sumber belajar dapat diperoleh dari dunia maya. Perkembangan internet, hand phone, maupun media lainnya sangat besar pengaruhnya terhadap minat belajar siswa. Materimateri pembelajaran dapat di-download dari internet dengan cepat dan efisien bahkan ada yang gratis.

Berdasarkan masalah di atas maka penulis terdorong untuk melakukan penelitian tentang "Pengaruh Penggunaan Media Internet Terhadap MinatBelajar Siswa Muslim di SMP Kota Pekanbaru".

Adapun rumusan masalah dalam penelitian ini adalah sebagai berikut:

1) Bagaimana gambaran pengaruh penggunaan media internet pada siswa Muslim?

2) Bagaimana gambaran minat belajar siswa Muslim?

3) Apakah terdapat pengaruh penggunaan media internet terhadap minat belajar siswa Muslim?

Sesuai dengan rumusan masalah yang dikemukakan di atas maka tujuan umum dalam penelitian ini adalah untuk mendeskripsikan:

1) Gambaran pengaruh penggunaan media internet pada siswa Muslim

2) Gambaran minat belajar siswa Muslim

3) Terdapat pengaruh penggunaan media internet terhadap minat belajar siswa Muslim.

\section{LANDASAN TEORI \\ Minat Belajar}

Minat belajar merupakan

kecenderungan individu untuk merasa senang dalam melakukan sesuatu yang disukainya (Selvy Desiana \& Saefur Rochmat 2018). Minat belajar berkaitan dengan perasaan suka atau senang dari seseorang terhadap sesuatu objek. Hal ini didukung juga oleh Slameto (2003: 180) yang menyatakan bahwa minat sebagai suatu rasa lebih suka dan rasa keterikatan pada suatu aktivitas, tanpa ada yang menyuruh. Minat pada dasarnya adalah penerimaan akan suatu hubungan antara diri sendiri dengan sesuatu di luar diri.

Menurut Kartono (2000: 12) minat merupakan momen dan kecendrungan yang searah secara intensif kepada suatu objek yang dianggap penting. Sedangkan Slameto (2003: 57) menjelaskan bahwa minat adalah yang tetap untuk memperhatikan dan mengenang beberapa kegiatan.

Selanjutnya Slameto (2008: 12) mengungkapkan bahwa suatu minat dapat diekspresikan melalui suatu hal dari pada hal lainnya. Biologi merupakan ilmu yang mempelajari tentang kehidupan. Semua benda yang hidup menjadi obyek dari biologi. Biologi sebagai salah satu bidang ilmu pengetahuan juga merupakan objek pada aspek minat.

Dengan demikian, bidang biologi dapat melahirkan reaksi perasaan senang, gembira, dan semangat belajar, begitu juga sebaliknya tergantung dari kepribadian siswa sendiri apakah menaruh minat yang tinggi terhadap biologi atau tidak (Ahmadi, 2010: 12).

Dari pendapat para ahi diatas peneliti mengambil kesimpulan bahwa timbulnya minat seseorang itu disebabkan oleh beberapa faktor penting yaitu faktor intern dan ekstern. Adapun faktor intern terdiri dari perhatian, tertarik, dan aktifitas, sedangkan faktor ekstern terdiri dari keluarga, sekolah, dan lingkungan.

Menurut (Gie, 2012: 10) minat dan perhatian dalam belajar mempunyai 
hubungan yang erat sekali. Seseorang yang menaruh minat pada mata pelajaran tertentu, cenderung untuk memperhatikan mata pelajaran tersebut. Sebaliknya, bila seseorang menaruh perhatian secara kontinyu baik secara sadar maupun tidak pada objek tertentu, biasanya dapat membangkitkan minat pada objek tersebut.

Menurut Sukardi (2009: 23) bahwa minat belajar adalah salah satu bentuk keaktifan seseorang yang mendorong untuk melakukan serangkaian kegiatan jiwa dan raga untuk memperoleh suatu perubahan tingkah laku sebagai hasil dari pengalaman individu dalam interaksi dalam lingkungannya yang menyangkut kognitif, afektif, dan psikomotorik.

Menurut Slameto (2010: 180) bahwa minat belajar adalah pilihan kesenangan dalam melakukan kegiatan dan dapat membangkitkan gairah seseorang untuk memenuhi kesediaanya dalam belajar.

Dengan memperhatikan pengertian minat belajar tersebut, maka semakin kuatlah kesimpulan tentang anggapan bahwa minat belajar adalah suatu hal yang abstrak (tidak bisa dilihat secara langsung dengan mata kepala), namun dengan memperhatikan dari aktivitas serta halhal lain yang diilakukan oleh seseorang minat belajar tersebut bisa diketahui dengan cara menyimpulkan dan menafsirkan Abu Ahmadi Widodo (2001: 121).

\section{Faktor-faktor yang Mempengaruhi Minat Belajar}

Faktor-faktor yang mempengaruhi minat belajar terbagi menjadi 2 yaitu:

a. Faktor internal

Faktor kebutuhan: Minat dari seorang anak adalah petunjuk langsung dari kebutuhan anak tersebut. Seorang anak yang membutuhkan penghargaan status, misalnya ia akan mengembangkan minatnya pada semua aktivitas dimanapun ia sebagai upaya untuk memuaskan kebutuhan itu.
Keinginan dan cita-cita: pada umumnya keinginan dan cita-cita anak itu didasarkan pada 3 kebutuhan yaitu kebutuhan akan perasaan aman, kebutuhan akan memperoleh status, kebutuhan akan memperoleh penghargaan. Bakat: Seorang anak yang memiliki bakat pada suatu keterampilan akan cenderung menekuninya dengan perhatian yang besar, sehingga akan terus berminta untuk aktif berkecimpung didalamnya.

b. Faktor Eksternal

Kebudayaan: seringkali keinginan atau hal-hal yang tidak diinginkan oleh anak-anak adalah hasil dari tekanan kebudayaan. Dan sifat egosentrik menunjukan bahwa minta adalah suuatu usaha-usaha anak untuk melakukan sesuatu yang membawa sukses. Faktor penngalaman: pengalaman yang telah dirasakan seorang anak akan membentuk minat anak. Seorang anak memiliki minat membaca dan ia memiliki kesempatan itu, maka ia akan terus berminat kearah itu, sebaliknya seorang yang tidak memiliki kesempatan untuk mengembangkan minat itu, maka potensi akan terbuang.

c. Faktor Keluarga

Sebagaimana Jalaludin (2003: 12) menyatakan bahwa: keluarga menurut para pendidik merupakan lapangan pendidikan yang pertama, dan pendidiknya adalah kedua orang tua. Orang tua (Bapak \& Ibu) adalah pendidik kodrati. Mereka pendidik bagi anak-anaknya karena secara kodrat, Bapak dan Ibu diberikan anugerah oleh Tuhan Pencipta berupa naluri orang tua.

d. Faktor Sekolah

Disekolah itulah siswa diberi beberapa ilmu pengetahuan dan percontohan yang baik, akhirnya mengalami perubahan baik kognitif, afektif, maupun psikomotorik. Dengan demikian apabila sekolah tersebut baik, tentunya perubahan dan 
perkembangan dari anak juga baik. Jelasnya guru dan teman-teman sekolah, tugas-tugas sekolah dan peralatannya, peraturanya, keseluruhannya menantang siswa untuk menyesuaikan diri, pergaulan anak dengan lingkungn (sekolah) dapat membentuk karakter anak.

e. Faktor Masyarakat

Pendidikan adalah suatu lemaga masyarakat yang digunakan untuk mewariskan nilai-nilai yang ada pada masyarakat. Hal ini dikatakan bahwa pendidikan harus dipandang sebagai infuisi penyiapan anak didik untuk mengenali hidup dan kehidupan itu sendiri. Tradisi yang ada pada masyarakat akan mempengaruhi jiwa anak, tradisi yang baik tentunya akan membawa pengaruh yang positif dan tradisi yang jelek akan membawa pengaruh negative. Menurut Zuhairini (2000: 11) masyarakat mempunyai rencana yang sangat penting terhadap berhasil tidaknya pendidikan, karena perkembangan jiwa anak itu juga dipengaruhi oleh keadaan lingkungan dan pengaruh tersebut terutama datang dari teman sebayanya dan masyarakat sekitarnya. Dari uraian tersebut maka penulis dapat menyimpulkan bahwa minat belajar seseorang tidak dapat dilihat secara langsung dengan mata kepala namun minat belajar juga berasal dari factor internal dan eksternal seseorang.

f. Indikator Minat Belajar Siswa

Indikator minat ada empat, yaitu perasaan senang, ketertarikan siswa, perhatian siswa, dan keterlibatan siswa. Berikut ini penjelasan dari masing-masing indikator yang dapat memunculkan minat belajar bagi seorang siswa:

\section{Perasaan Senang}

Seorang siswa yang memiliki perasaan senang atau suka terhadap suatu mata pelajaran, maka siswa tersebut akan terus mempelajari ilmu yang disenanginya. Tidak ada perasaan terpaksa pada siswa untuk mempelajari bidang tersebut.

2. Ketertarikan Siswa

Berhubungan dengan daya gerak yang mendorong untuk cenderung merasa tertarik pada orang, benda, kegiatan atau bisa berupa pengalaman afektif yang dirangsang oleh kegiatan itu sendiri.

\section{Perhatian Siswa}

Perhatian merupakan konsentrasi atau aktivitas jiwa terhadap pengamatan dan pengertian, dengan mengesampingkan yang lain dari pada itu. Siswa yang memiliki minat belajar pada objek tertentu, dengan sendirinya akan memperhatikan objek tersebut.

4. Keterlibatan Siswa

Ketertarikan seseorang akan suatu objek yang maengakibatkan orang tersebut senang dan tertarik untuk melakukan atau mengerjakan kegiatan dari objek tersebut.

\section{Pengertian Internet}

Secara harfiah, internet (kependekan dari kata "inter-network") ialah rangkaian komputer yang terhubung melintasi beberapa rangkaian. Manakala Internet (huruf 'I' besar) ialah system computer umum, yang terhubung secara global menggunakan TCP/IP sebagai protokol pertukaran paket (packet switching communication protokol) (Muadz, 2007: 2).

Sidharta (2002: 12) memberikan defenisi yang sangat luas terhadap internet. Internet adalah forum global pertama dan perpustakaan global pertama dimana setiap pemakai dapat berpartisipasi dalam segala waktu. Karena internet merupakan perpustakaan global, maka pemakai dapat memanfaatkannya sebagai media pembelajaran.

Moh. Surya (2005: 32) internet merupakan sebuah alat yang dapat menunjang proses pembelajaran dan juga dapat mempermudah siswa dalam 
pengerjaan tugas-tugas dari sekolah. Namun, pengaruh negatif internet berdampak pada minat belajar siswa, tidak sedikit siswa lebih memilih bermain internet dengan situs-situs jejaring sosial dan game online daripada belajar atau mengerjakan tugas-tugas dari sekolah.

Muadz (2007: 13) Internet memang banyak manfaatnya banyak menambah wawasan dan pengetahuan bagi siswa. Namun, kenyataanya ada sebagian siswa yang tidak memanfaatkan internet untuk memudahkan proses pembelajarannya, padahal minat belajar siswa sangat berpengaruh dalam keberhasilan proses pembelajaran.

Menurut Ibrahim (2012: 64) bahwa kata media merupakan bentuk jamak dari kata medium yang dapat didefinisikan sebagai perantara atau pengantar terjadinya komunikasi dari pengirim menuju penerima. Sedangkan menurut Bovee (dalam Ibrahim 2007:64) media merupakan sebuah alat yang mempunyai fungsi menyampaikan pesan.

Sedangkan Menurut Ismawati (2010: 20) bahwa penggunaanmedia pembelajaran seperti internet berpengaruh terhadap minat belajarsiswa.

Dari beberapa pendapat diatas dapat disimpulkan bahwa internet adalah suatu jaringan informasi berbagai komputer yang terhubung dan berkomunikasi satu sama lain yang digunakan sebagai sumber dan media dari berbagai pengetahuan.

\section{Sejarah Internet}

Internet adalah suatu jaringan computer yang pertama kali dibentuk oleh Departemen Pertahanan Amerika Serikat di tahun 1969, dengan proyek ARPA yang disebut ARPANET. ARPA NET kepanjangan dari Advanced Research Project Agency Network yang mendemonstrasikan cara suatu hadware dan software computer memliki basis UNIX dengan berkomunikasi dlam jarak jauh dengan sarularan telepon.

ARPANET di tahun 1969 awalnya hanya dapat menghubungkan 4 situs seperti Stnford Research Institute, University of California, Santa Barbara, University of Utah. Lalu di bulan Oktobet 1972 ARPANET dikenalkan secara umum $\mathrm{dn}$ berkembang pesat diseluruh wilayah sampai ARPANET kesulitan. Dari kesulitan tersebut ARPANET di pecah menjadi dua yaitu MILNET untuk keperluan militer dan ARPANET untuk keperluan non-militer. Seiring berjalanya waktu, masyarakat dikenal dengan nama DARPA dan disederhanakan menjadi Internet seperti sekarang ini.

Perkembangan Internet Saat Ini, saat ini internet dikelola dan dijaga oleh perjanjian multilateral dan protocol yang menampilkan perpindahan data antara rangkaian. Protocol di bentuk berdasarkan perbincangan Internet Engineering Task Force (IETF) yang terbuka secara umum. Badan yang mengeluarkan sebuah dokumen yang dikenal dengan RFC yaitu Request For Comment yang sebagian datanya dijadikan sebagai standar Internet oleh Badan Arsitektuur Internet. Protocolprotokol internet yang biasa digunakan adalah IP, TCP, UDP, DNS, IMAP, SMPTP, HTTPS, FTP, SSL, HTTP,LDAP, dll.

\section{Pengaruh Penggunaan Media Internet Terhadap Minat Belajar Siswa Muslim}

Menurut Muhibbin Syah (2005: 132-

139) Pemanfaatan internet sebagai sumber belajar merupakan salah satu upaya untuk membantu kegiatan belajar agar lebih efektif karena kekayaan informasi yang tersedia. Selain itu internet juga dapat diakses oleh para siswa tanpa batas ruang dan waktu. Sehingga internet akan mempermudah siswa untuk memperoleh informasi yang berhubungan dengan dunia pendidikan. Sedangkan minat belajar merupakan factor intern dari siswa itu sendiri untuk menunjang kegiatan belajar.

Menurut Arsyad Azhar (2009: 12) Siswa yang memiliki minat belajar yang tinggi akan belajar dengan kesadaran dalam diri atau bukan karena ada paksaan 
dari orang lain. Mengacu pada analisa dan pendapat diatas maka diinterprestasikan bahwa pemanfaatan internet sebagai sumber belajar dan minat belajar yang tinggi dapat meningkatkan prestasi belajar karena semakin banyak siswa yang mengakses internet sebagai sumber belajar.

Dari beberapa pendapat para ahli di atas dapat disimpulkan bahwa Pemanfaatan media internet sebagai sumber belajar dan adanya minat belajar yang tinggi dapat meningkatkan prestasi belajar karena semakin banyak siswa yang mengakses internet sebagai sumber belajar maka akan meningkat juga minat belajar siswa.

\section{Kerangka Berpikir}

Kerangka berfikir yaitu gambaran atau pola hubungan antar variable atau kerangka konseptual yang akan digunakan untuk memecahkan masalah yang diteliti, disusun berdasarkan kajian yang telah dilakukan.

Seorang guru diharapkan bisa mengarahkan siswanya untuk menambah waktu belajarnya dengan mengakses internet dan juga seorang guru harus mampu memberikan pengarahan dan penjelasan tentang kerugian-kerugian dalam mengakses internet karena internet merupakan sebuah dunia tanpa penguasa, yang artinya semua orang mempunyai hak yang sama di internet.

Penggunaan internet dalam pendidikan memang mempunyai pengaruh yang sangat besar di dalam pribadi siswa. Siswa memang harus dituntun untuk menggunakan tegnologi internet tersebut secara bijak. Banyak terjadi kejadian yang dilakukan oleh siswa dalam menggunakan internet, misalnya siswa membuka situs-situs porno yang seharusnya tidak dilakukan oleh para generasi bangsa. Memang para guru juga dituntut untuk mengajarkan cara menggunakan internet tersebut dengan benar dan tidak menggunakan internet tersebut untuk kejahatan.

Dengan pengetahuan internet diharapkan siswa dapat menambah wawasan ilmu pengetahuanya sehingga minat belajar bisa betambah dan prestasi belajarnya pun bisa ditingkatkan.

\section{Gambar 2.1}

$(\mathrm{X})$

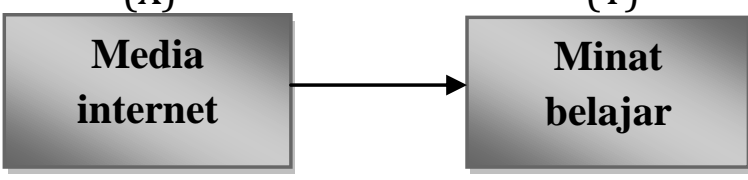

Teori Syafrudin Utomo. 2009.

\section{METODE}

Penelitian ini termasuk dalam penelitian deskriptif kuantitatif regresi. Penelitian ini bertujuan untuk melihat pengaruh antara penggunaan media internet terhadap minat belajar siswa Muslim. Hasilnya akan diinterpretasikan dengan analisis deskriptif dan inferensi. Menurut Sugiyono(2015) Metode deskriptif kuantitatif analisis regresi digunakan untuk memeriksa, mencatat, menganalisis, dan menginterpretasikan variabel antara penggunaan media internet terhadap minat belajar siswa Muslim. Variabel bebas dalam penelitian ini yaitu penggunaan media internet sedangkan variabel terikatnya yaitu minat belajar siswa.

populasi dalam penelitian ini adalah Siswa SMP Kota Pekanbaru seramai 35.368 siswa. Jenis pengambilan sampel dalam penelitian ini menggunakan teknik Simple random sampling. Pengambilan sampel dengan Simple random sampling ini dengan tujuan memberikan kesempatan sama kepada semua siswa menjadi sampel (Yusuf, 2013: 160). Sampel di ambil 5\% dari populasi yang didapati oleh peneliti sebanyak 350 siswa.

Penelitian ini menggunakan angket/kuesioner yaitu angket pengaruh media internet dan angket minat belajar. Angket telah uji coba reliabilitas menggunakan sampel 50 siswa SMP dengan didapati alpha Cronbach.

Teknik analisis data menggunakan Software SPSS. Deskripsi data dengan 
mean dan Faktor pengaruh menggunakan Regresi.

\section{Uji Coba Instrument}

Sebelum angket disebar kepada responden, maka terlebih dahulu dilakukan uji coba instrument tersebut. Uji coba dimaksudkan untuk mengetahui validasi dan realibitas instrument yang digunakan sehingga hasil yang diperoleh dari instrument tersebut dapat diyakini.

Untuk mendapatkan kehandalan alat ukur secara utuh atau reabilitas instrumen, dicari koefisien korelasi dan dimasukkan dalam rumus Spearman Brown Riduwan (2005: 102).

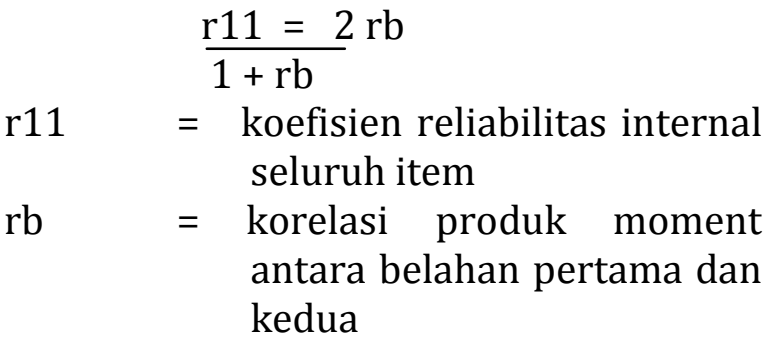

Skala Davis (1971) menjadi dasar untuk mengetahui tinggi atau rendahnya ujia realibilitas yaitu lebih atau sama dengan 0.70 dikatakan mempunyai hubungan yang sangat tinggi. Nilai reabilitas 0.5 hingga 0.69 menunjukkan hubungan yang tinggi. Nilai reabilitas 0.3 hingga 0.49 menunjukkan bahwa hubungan yang sederhana tinggi. Hubungan rendah pula bagi nilai reabilitas 0.1 hingga 0.29 sedangkan hubungan yang bisa diabaikan bagi nilai reabilitas 0.01 hingga 0.09 .

\section{Tabel1 Skala Davis Bagi Korelasi} Realibilitas

\begin{tabular}{|c|l|}
\hline Nilai Realibilitas & \multicolumn{1}{|c|}{ Tafsiran Realibilitas } \\
\hline 0.70 hingga 1.00 & Korelasi Sangat Tinggi \\
\hline 0.50 hingga 0.69 & Korelasi Tinggi \\
\hline 0.30 hingga 0.49 & Korelasi Sederhana Tinggi \\
\hline 0.10 hingga 0.29 & Korelasi Rendah \\
\hline 0.01 hingga 0.09 & Korelasi yang diabaikan \\
\hline
\end{tabular}

Sumber : Davis 1971

Dalam penelitian ini telah di dapati uji realibilitas dengan menggunakan 50 siswa SMP untuk menjadi sampel dalam uji realibilitas instrument penelitian. Hasil uji coba instrument pengaruh media internet dengan Alpha Cronbanch adalah .86. Sedangkan Minat Belajar didapati Alpha Cronbach adalah . 83.

Tabel 2

Uji Realibilitas Instrumen Penelitian

\begin{tabular}{|l|l|l|}
\hline No & Instrumen & $\begin{array}{l}\text { Alpha } \\
\text { Cronbach }\end{array}$ \\
\hline 1. & Pengaruh Media Internet & .86 \\
\hline 2. & Minat Belajar & .83 \\
\hline
\end{tabular}

Sumber Data: Hasil Olahan 2017

\section{HASIL}

\section{Analisis Deskriptif}

\section{a. Gambaran pengaruh media internet} siswa SMP Kota Pekanbaru.

Untuk memperoleh hasil penelitian tentang Pengaruh Media Internet SiswaMuslim Riaumaka peneliti menggunakan analisis deskriptif. Oleh itu, untuk mengetahui gambaran umum mengenai data penelitian secara singkat dapat dilihat pada tabel deskriptif data penelitian yang berisikan fungsi-fungsi statistik dasar yang disajikan secara lengkap pada tabel berikut ini.

\section{Tabel 3 Deskriptif Pengaruh Media Internet Siswa SMP Kota Pekanbaru}

\begin{tabular}{|l|c|c|c|c|c|c|}
\hline & $\mathrm{N}$ & $\begin{array}{c}\text { Skor } \\
\text { Mean }\end{array}$ & $\begin{array}{c}\text { Standar } \\
\text { Deviasi }\end{array}$ & Minimum & Maksimum & Kategori \\
\hline $\begin{array}{l}\text { Pengaruh Media } \\
\text { Internet - Sikap }\end{array}$ & 350 & 74.64 & 12.708 & 41.00 & 99.00 & Tinggi \\
\hline
\end{tabular}

Berdasarkan tabel 3 diatas didapati bahwa skor minimum terletak pada skor 26 dan skor maksimum terletak pada skor 48. Selain daripada itu, skor min Pengaruh Media Internet bagian sikap menunjukkan skor yang $(\mathrm{M}=36.95, \mathrm{SD}=3.076)$ dan berada pada tahap interpretasi yang sederhana. Sehingga dapat disimpulkan bahwa Pengaruh Media Internet bagian sikap subjek dalam penelitian ini berada dalam kategori sederhana. 


\section{b. Gambaran Minat Belajar siswa SMP Kota Pekanbaru.}

Untuk memperoleh hasil penelitian tentang minat belajar siswabagi siswa muslimmaka peneliti menggunakan analisis deskriptif. Oleh itu, untuk mengetahui gambaran umum mengenai data penelitian secara singkat dapat dilihat pada tabel deskriptif data penelitian yang berisikan fungsi-fungsi statistik dasar yang disajikan secara lengkap pada tabel berikut ini.

Tabel 4 Deskriptif Minat Belajar Siswa SMP Kota Pekanbaru

\begin{tabular}{|l|c|c|c|c|c|c|}
\hline & $\mathrm{N}$ & Skor Mean & $\begin{array}{c}\text { Standar } \\
\text { Deviasi }\end{array}$ & Minimum & Maksimum & Kategori \\
\hline $\begin{array}{l}\text { Minat } \\
\text { Belajar }\end{array}$ & 350 & 71.20 & 11.762 & 39.00 & 95.00 & Tinggi \\
\hline
\end{tabular}

Berdasarkan tabel 6 diatas didapati bahwa skor minimum terletak pada skor 34 dan skor maksimum terletak pada skor 100. Selain daripada itu, skor min Minat Belajarmenunjukkan skor yang $(\mathrm{M}=$ 41.61, SP = 7.256) dan berada pada tahap interpretasi yang tinggi. Sehingga dapat disimpulkan bahwa Minat Belajar subjek dalam penelitian ini berada dalam kategori tinggi.

\section{ANALISIS INFERENSI}

Tujuan statistik inferensi digunakan adalah untuk menjelaskan ciri-ciri berkaitan populasi dengan menggunakan data daripada sampel. Kaedah statistik menggunakan inductive reasoning. Dalam inductive reasoning, jika andaian itu adalah benar, ketika kesimpulan itu dibuat dan mengikuti dengan beberapa hipotesis dan suatu tuntutan boleh mengandungi informasi baru untuk memberikan hujjah dan tidak disampaikan sebagai bukti dalam memberi hujjah.

\section{a. Perngaruh Media Internet terhadap Minat Belajar SMP Kota Pekanbaru.}

$\mathrm{H}_{\mathrm{o} 1}$ : Tidak terdapat pengaruh yang signifikan antara Pengaruh Media Internet terhadap Minat Belajar dalam kalangan siswa.

Bagi melihat pengaruh yang signifikan antara Pengaruh Media Internet terhadap Minat Belajar dalam kalangan siswa maka perlu dilihat dahulu linier untuk mengetahui adakah terdapat hubungan linier antara variabel $\mathrm{X}$ dan variabel Y. Apabila nilai signifikan $>0.05$ maka dapat disimpulkan terdapat hubungan linier. Maka boleh dilaksanakan regresi. Maka hasil linier pada penelitian ini dapat dilihat tabel 9.

Tabel 5Hasil Uji Linieritas

\begin{tabular}{|c|c|c|c|c|c|c|}
\hline \multicolumn{7}{|c|}{ ANOVA Tabel } \\
\hline & & Sum of Squares & $\mathrm{df}$ & Mean Square & $\mathrm{F}$ & Sig. \\
\hline $\begin{array}{l}\text { PengaruhMediaIntern } \\
\text { et* }\end{array}$ & $\begin{array}{l}\text { Deviation from } \\
\text { Linearity }\end{array}$ & 1.753 & 349 & 0.68 & 1.891 & 0.425 \\
\hline
\end{tabular}

Berdasarkan tabel 9 di atas dapat dilihat bahwa model regresi mengalami hubungan linieritas antara variabel $X$ dengan variabel Y. Hal ini menunjukan signifikansi $(0.425)>0.05$ maka dapat disimpulkan terdapat hubungan yang linier antara variabel bebas dengan variabel terikat.

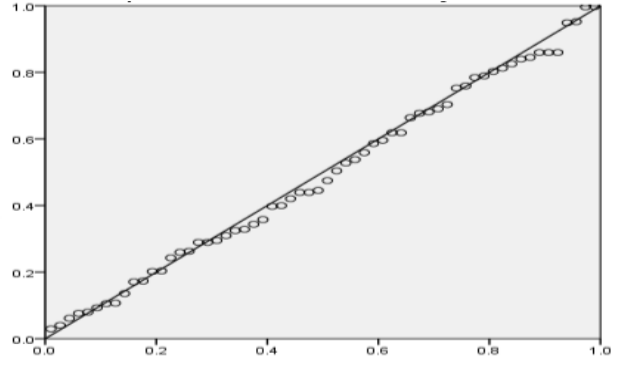

Gambar 1

Hasil Uji Normal 
Pada gambar 1 dapat dilihat bahwa grafik normal probability plot menunjukkan pola grafik yang normal. Hal ini terlihat dari titik yang menyebar di sekitar grafik normal. Hal ini terlihat dari titik-titik yang menyebar disekitar garis diagonal dan penyebarannya mengikuti garis diagonal. Oleh itu, dapat disimpulkan bahwa model regresi layak digunakan kerana memenuhi asumsi normal.

Selepas itu, analisis regresi boleh digunakan dalam penelitian ini dengan tujuan untuk mengenalpasti adakah terdapat pengaruh yang signifikan antara Pengaruh Media Internet terhadap Minat Belajar dalam kalangan siswa.

Tabel 6

Hasil uji regresi Pengaruh Media Internet (X) dengan Minat Belajar (Y)

\begin{tabular}{|l|l|l|l|l|l|l|}
\hline \multicolumn{2}{|c|}{ Model } & \multicolumn{2}{c|}{$\begin{array}{c}\text { Cnstandardized } \\
\text { Coefficients }\end{array}$} & $\begin{array}{c}\text { Standardized } \\
\text { Coefficients }\end{array}$ & Sig. \\
\cline { 3 - 7 } \multicolumn{2}{|c|}{} & B & $\begin{array}{c}\text { Std. } \\
\text { Error }\end{array}$ & Beta & \\
\hline \multirow{2}{*}{1} & (Constant) & 0.117 & .139 & & 14.522 & .000 \\
\cline { 2 - 7 } & $\begin{array}{l}\text { Pengaruh_Media } \\
\text { Internet }\end{array}$ & 0.155 & .046 & .291 & 3.103 & .000 \\
\hline
\end{tabular}

Dari tabel 6 di dapat persamaan regresinya adalah sebagai berikut $\ddot{Y}=$ $0.117+0,155 \mathrm{X}$. Hasil analisis data daripda SPSS version 22.0 menunjukkan bahwa setiap kenaikan pengaruh yang signifikan antara Pengaruh Media Internet terhadap Minat Belajar dalam kalangan siswa sebesar 0,155Xpada kostant 0.117 pada siswaSMP Kota Pekanbaru.

Untuk uji koefisien determinan antara Pengaruh Media Internet (X) dengan Minat Belajar (Y) dapat dilihat pada tabel 7 di bawah ini :

Tabel 7

Hasil uji kekuatan antara variabel Pengaruh Media Internet (X) dengan Minat Belajar (Y)

\begin{tabular}{|c|c|c|c|c|c|c|c|c|c|}
\hline \multicolumn{10}{|c|}{ Model Summaryb } \\
\hline \multirow[t]{2}{*}{ Model } & \multirow[t]{2}{*}{$\mathrm{R}$} & \multirow{2}{*}{$\begin{array}{l}\mathrm{R} \\
\text { Square }\end{array}$} & \multirow{2}{*}{$\begin{array}{l}\text { Adjusted } \\
\text { R Square }\end{array}$} & \multirow{2}{*}{$\begin{array}{l}\text { Std. } \\
\text { Error of } \\
\text { the } \\
\text { Estimate }\end{array}$} & \multicolumn{5}{|c|}{ Change Statistics } \\
\hline & & & & & $\begin{array}{l}\text { R Square } \\
\text { Change }\end{array}$ & $\begin{array}{l}\mathrm{F} \\
\text { Change }\end{array}$ & df1 & df2 & $\begin{array}{l}\text { Sig. F } \\
\text { Change }\end{array}$ \\
\hline 1 & $\begin{array}{l}.89 \\
1^{\mathrm{a}}\end{array}$ & .846 & .838 & .13412 & .832 & 215.117 & 2 & 348 & .000 \\
\hline
\end{tabular}

Dari tabel 7 di atas dapatan menunjukkan bahwa kekuatan hubungan antara Pengaruh Media Internet (X) dengan Minat Belajar (Y) sebesar 0,891. Dari tabel diatas maka dapat disimpulkan bahwa kekuatan hubungan antara variabel dinyatakan sangat kuat. Kemudian untuk koefisien determinan $\left(\mathrm{r}^{2}\right)$ pada tabel di atas variabel Minat Belajar (Y) memberi pengaruh terhadap Pengaruh Media Internet (X) sebesar 0,846 atau $84,6 \%$ selain itu, sisanya $15,4 \%$ dipengaruhi oleh faktor lain.
Dengan demikian disimpulkan bahwa Pengaruh Media Internet memberi pengaruh yang tinggi terhadapMinat Belajar.

\section{PEMBAHASAN}

Analisis deskriptif pada Pengaruh Media Internet bahagian Sikap Siswa SMPdidapati bahwa skor minimum terletak pada skor 41 dan skor maksimum terletak pada skor 99. Selain daripada itu, skor min Pengaruh Media Internet bagian sikap menunjukkan skor yang $(\mathrm{M}=74.64$, 
SD = 12.708) dan berada pada tahap interpretasi yang tinggi. Sehingga dapat disimpulkan bahwa Pengaruh Media Internet bagian sikap subjek dalam penelitian ini berada dalam kategori tinggi. Berbeda dengan hasil penelitian Sani (2011) yang menyatakan bahwa hasil deskriptif Pengaruh Media Internet memiliki intepretasi yang rendah yang di sebabkan masih rendahnya tahap Pengaruh Media Internet bagi siswa. Namun dalam penelitian Jasmi (2014) menyatakan sikap Pengaruh Media Internet pada siswa memiliki pada tahap sederhana. Berarti berbeda juga hasil penelitian yang dilaksanakan. Hasil penelitian Crites \& Savickas (1995) berbeda dengan hasil penelitian ini karena siswa masih berumur 18 hingga 24 tahun yang memiliki pada tahap penerokaan yang dalam teori Ginzberg (1956) menyatakan manusia pada umur 18-24 tahun masih belum matang dalam pengambilan keputusan karir.

Selain itu, analisis deskriptif pada minat belajar siswa didapati bahwa skor minimum terletak pada skor 39 dan skor maksimum terletak pada skor 95. Selain daripada itu, skor min Minat Belajarmenunjukkan skor yang $(\mathrm{M}=$ 71.20, $\mathrm{SD}=11.762$ ) dan berada pada tahap interpretasi yang tinggi. Sehingga dapat disimpulkan bahwa Minat Belajar subjek dalam penelitian ini berada dalam kategori tinggi. Hasil penelitian Christoper, Andrew \& Paul, (2009) sama hasil nya yang menyatakan bahwa minat belajar siswa memiliki keinginan yang tinggi. Berbeda dengan penelitian (Majogoro \& Ngabo, 2012; Norhazlin, Nahariah, \& Tan Sio, 2013) menjelaskan bahwa siswa masih rendah minat belajar karena pengaruh media internet.

Bagi analisis statistik inferensiujian regresi pada pengaruh media Internet terhadap minat belajar siswa yang didapati hasil penelitian menunjukkan bahwa kekuatan hubungan antara Pengaruh Media Internet (X) dengan
Minat Belajar (Y) sebesar 0,891. Dari hasil penelitian dapat disimpulkan bahwa kekuatan hubungan antara variabel dinyatakan sangat kuat. Kemudian untuk koefisien determinan $\left(\mathrm{r}^{2}\right)$ pada tabel di atas variabel Minat Belajar (Y) memberi pengaruh terhadap Pengaruh Media Internet $(\mathrm{X})$ sebesar 0,846 atau 84,6\% selain itu, sisanya $15,4 \%$ dipengaruhi oleh faktor lain. Dengan demikian disimpulkan bahwa Pengaruh Media Internet memberi pengaruh yang tinggi terhadapMinat Belajar. Menurut Norasmah, Nor Hafiza, Rahmah \& Poo Been (2012) menyatakan bahwa tingkah laku siswa dalam minat belajar memiliki pengaruh pada seberapa tinggi atau rendah nya Pengaruh Media Internet siswa tersebut. Karena tingginya Pengaruh Media Internet siswa maka akan lebih susah untuk minat belajar yang disebabkan tidak diatur waktu untuk belajar dan untuk bermain internet. Berbeda dengan Winarno (2013) dalam penelitian mempelajari siswa yang pengaruh media internet memberi pengaruh positif bagi siswa. Siswa semakin tinggi minat belajar disebabkan media pembelajaran dan tugas sekolah didapati di internet. Oleh itu, Pengaruh media internet ini adakala nya memberi dampak negative dan adakala nya memberi dampak positif bagi yang menggunakan media internet.

\section{PENUTUP}

Kajian ini dapat disimpulkan bahwa pengaruh faktor media internet terhadap minat belajar siswa SMP Kota Pekanbaru memiliki pengaruh terhadap siswa di sekolah. Analisis kajian memiliki makna bagi siswa yang memberi pengaruh positif terhadap media internet. Oleh karena itu, minat belajar siswa memiliki tinggi apabila media internet dapat digunakan oleh siswa dengan maksimal. Tugas-tugas yang ada diberi guru terhadap siswa dapat digunakan media internet untuk mendapati referensi tugas-tugas sekolah 
dan mencari pengetahuan dan pemahaman pembelajaran di sekolah.

Dengan demikian guru di sekolah perlu mendidik siswa di sekolah dengan cermat dan teliti. Tentunya bagi guru Pendidikan Agama Islam dan juga guru Bimbingan dan Konseling perlu memberikan pengetahuan dan pemahaman serta layanan informasi serta orientasi dalam penggunaan media internet bagi pemanfaatan hal yang positif. Akhirnya dapatlah disimpulkan bahwa pengaruh media internet terhadap minat belajar siswa memiliki pengaruh yang tinggi. Dengan demikian, sekolah perlu memberi pemahaman dan orientasi kepada siswa terhadap pemanfaatan media internet.[] 


\section{DAFTAR RUJUKAN}

Arif, Fulchan. Pengantar Penelitian dalam Pendidikan, Yogyakarta: Pustaka Pelajar, 2004.

Arsyad, Azhar. Media Pembelajara, Jakarta: Grafindo Persada, 2009.

Asnawirdan, M. Basyiruddin Usman. Media Pembelajaran, Jakarta: Ciputat Press, 2002.

Bimo, Walgito. Pengantar Pisikologi Umum, Jogyakarta: Andi Offset, 2004.

Davis, J.A. Elementary Survey Analysis. Englewood Cliffs, NJ: Prentice Hall, 1971.

Drajat, Zakiah. Metodik Khusus Penagajaran Agama Islam, Jakarta: Bumi Aksara, 1995.

Hamzah, B. Uno. Teori Motivasi dan Pengukurannya, Jakarta: Penerbit Bumi Aksara, 2006.

Hendri, Pondia. Teknologi Informasi Dan komonikasi, Jakarta: Erlangga, 2004.

Ibrahim, M. Model Pembelajaran Inovatif, Jakarta: Media Group, 2012.

Ismawati, Ita. Pengaruh Penggunaan Internet sebagai Sumber Belajar terhadap Prestasi Belajar Melalui Motivasi Belajar Siswa Kelas XI IPS SMA Negeri 1 Batu. Universitas Sumatra, 2011.

Konting, Mohd Majid. Kaedah Penyelidikan Pendidikan, Kuala Lumpur: Dewan Bahasa dan Pustaka, 1998.

Marwoto. "Strategi Guru Sejarah Dalam Meningkatkan Minat Belajar Siswa Pada Mata Pelajaran Sejarah Di Sman 10 Pekanbaru." Jurnal Lentera 5.14 (2014).

Prima Lestari., S. Pengaruh penggunaan media internet terhadap prestasi belajar ekonomi Siswa Kelas XII IPS SMA SWASTA BERSAMA BERASTAGI TA. 2011/2012, Sumatera Utara, Unimed: 2012.

Putra, Risky. Evaluasi Pembelajaran. Yogyakarta: Pustaka Belajar, 2009.
Sadirman, AM. Interaksi dan Motivasi Belajar, Jakarta: Raja Grapindo Persada, 2007.

Saifudijn, Azhar. Metode Penelitian, Yogyakarta: Pustaka Pelajar, 1998.

Sanafiyah, Faisal. Dasar Dan Peyusunan Angket, Surabaya: Usaha Nasional, 1982.

Sanjaya, Wina. Teknologi Komonikasi dan Informasi Pembelajaran, Jakarta: Bumi Aksara, 2010.

Slameto. Belajar dan Faktor- Faktor yang Mempengaruhi, Jakarta: Renika Putra, 2010.

Sugiyono. Metode Penelitian Kuantitatif, Kualitatif dan $R D$, Bandung: Alfabeta, 2010.

Sukardi. Mengembangkan Minat Baca Pada Anak, Bandung: Angkasa Ibrahim, 2009.

Sukirin. Pokok pokok Psikologi Pendidikan. Yogyakarta: Andi Offset, 1979.

Suprianto, Teknologi Informasi dan Komonikasi., Bogor: Yudistira, 2007.

Sutrino, Hadi. Metode Research II, Yogyakarta: Andi Offset, 1989.

Torang, Syamsir. Metode Riset Struktur dan Prilaku Organisasi, Bandung: Penerbit Alfabeta, 2012.

Wibowo, Agung Edy. Aplikasi Praktis SPSS dalam Penelitian, Yogyakarta: Gava Media, 2012.

Winarno. "Penerapan Sistem E-Learning Pada Komonitas Pendidikan Sekolah Rumah (Home Scholling)." Jurnal Utima 4.1 (2013): 45-51. 